\title{
KEBANGKITAN TUBUH MENURUT I KORINTUS 15:25-58 DAN IMPLIKASI ETIS
}

\author{
DANIK ASTUTI LUMINTANG
}

\section{PENDAHULUAN}

Kebangkitan tubuh atau orang mati dalam 1 Korintus 15:25-58 adalah misteri yang menjadi pokok bahasan hangat di sepanjang zaman. Hal ini dinyatakan sebagai misteri, karena masih menjadi perbincangan atau pertanyaan bagi banyak orang Kristen sendiri. Tidak sedikit orang Kristen yang memiliki doktrin yang benar, pengetahuan dan pemahaman yang cukup, namun doktrin atau pengetahuan dan pemahaman yang benar tersebut tidak nampak atau tidak tercermin pada sikap yang benar. Bahkan tidak sedikit orang Kristen yang bertanya, dengan tubuh apakah orang percaya dibangkitkan. Apakah dengan tubuh yang telah rusak, tubuh yang tercerai berai karena orang tersebut waktu meninggal mengalami kecelakaan, apakah benar tubuh itu yang dibangkitkan? dan apakah orang yang sudah meninggal, pada saat tubuh dibangkitkan, mereka dapat bertemu dengan keluarganya, seorang suami dapat bertemu dan melihat istrinya dengan tubuh yang dahulu dia lihat ataukah sebaliknya. Pertanyaan-pertanyaan tersebut hingga kini masih menjadi misteri bagi banyak orang, mereka belum mendapatkan jawaban yang benar. Karena itulah penulis ingin memberikan jawaban yang benar mengenai kebangkitan tubuh atau orang mati menurut surat 1Korintus 15:25-58.

\section{MISTERI KEBANGKITAN TUBUH (15:25-58)}

Bagian pertama dari surat pertama Korintus 15:1-11, telah dilaporkan mengenai fakta kebangkitan Kristus yang merupakan dasar kebangkitan orang percaya. Pada bagian kedua, yaitu ayat 12-34, telah dipaparkan mengenai kebangkitan orang mati yang membahas dua hal penting yaitu, akibat yang terjadi apabila tidak ada kebangkitan Kristus (ay. 12-19), dan akibat yang dihasilkan oleh kebangkitan Kristus bagi orang percaya (ay. 20-34). Sedangkan dalam bagian ini, penulis ingin menjelaskan satu misteri dari kebangkitan tubuh, yang merupakan kontinuitas dan perkembangan tentang kebangkitan Kristus. Secara khusus 
disini, Paulus ingin menjelaskan kebangkitan tubuh yang masih menjadi misteri bagi banyak orang.

\section{Pertanyaan Mengenai Kebangkitan Orang Mati (ay. 35)}

Pokok pembahasan bagian ini adalah tentang dua pertanyaan yang diangkat oleh Paulus. Dalam teks Yunani, Paulus memulai dengan frasa Alla erei tij. Kata erei (verb. indic. fut. act. 3 per. plur) artinya berbicara atau berkata, ${ }^{1}$ dalam bentuk future indicatif, maka kata erei berarti akan menyahut, berkata. Kata itu diikuti oleh kata tij artinya seseorang, seorang pun, ${ }^{2}$ dan diawali oleh kata penghubung kontras yaitu Alla yang berarti tetapi. Dengan demikian, maka kalimat Alla erei tij diterjemahkan: "Tetapi seseorang akan menyahut atau berkata" Kalimat ini memberikan petunjuk bahwa, Paulus bukan menjawab pertanyaan yang sudah ada di dalam jemaat Korintus, namun pertanyaan ini diangkat oleh Paulus untuk mengantisipasi pertanyaan di sekitar hal kebangkitan tubuh, yang pasti muncul, sebagai kontinuitas pengajaran Paulus tentang kebangkitan orang mati (ay. 12-34). Dalam hal ini, kemungkinan besar ada beberapa jemaat (tidak tertentu) yang masih atau telah dipengaruhi oleh ajaran Saduki dan Yunani yang akan berkata bahwa tidak ada kebangkitan orang mati. ${ }^{3}$ Keraguan dan atau ketidakpercayaan mengenai kebangkitan dari seseorang (tidak tertentu) adalah berkisar pada pertanyaan, yaitu Bagaimanakah orang mati dibangkitkan? Dan dengan tubuh apakah mereka akan datang kembali?

\section{Jawaban Mengenai Kebangkitan Orang Mati (ay. 36-44)}

Sebelum Paulus memberikan suatu penjelasan mengenai dua pertanyaan yang pasti dipertanyakan oleh seseorang di Korintus, ia

1 Erei artinya reply, say; Aland Kurt, Analytical greek New Testament (Grand Rapids, Michigan: Baker Book House, 1981), 544; Horst Balz, Exegetical Dictionary of the New Testament (Grand Rapids, Michigan: Eerdmans, 1990), 347

${ }^{2} \mathrm{Tij}$, someone, anyone... 1 Cor. 15:35; William F. Arndt, A Greek -English Lexicon of The New Testament and Other Early Christian Literature (Chicago: The University of Chicago Press, 1979), 819

${ }^{3}$ Konsep Yunani: "sesudah mati, jiwa meninggalkan tubuh dan selanjutnya keberadaannya di tempat lain, tetapi bagi tubuh tidak ada harapan untuk bangkit"; Denis Green, Tafsiran Surat I Korintus (Malang: SAAT, 1992), 103; Paulus mengantisipasi jenis-jenis pertanyaan yang pasti akan diajukan oleh seseorang di Korintus; V.C. Pfitzner, Kesatuan dalam Kepelbagaian, Tafsiran atas Surat I Korintus (Jakarta: BPK Gunung Mulia, 2000), 316 
menyebutnya dalam ayat 36: afpwn (adj. pronom. voc. mask. sing. afpwn, on) artinya bodoh, tolol, ${ }^{4}$ dalam bentuk kata benda berarti orang bodoh. Kata ini ditempatkan pada awal kalimat dan dalam bentuk vokatif (kata seruan) dapat diterjemahkan seperti terjemahan LAI yaitu "Hai orang bodoh!" Kata bodoh ini, Paulus tujukan kepada orang-orang yang mempertanyakan kebangkitan orang mati (ay. 35), mereka disebut oleh Paulus sebagai orang bodoh. ${ }^{5}$ Kebodohan mereka ternyata adalah bertolak dari ketidakpercayaan mereka terhadap hal kebangkitan orang mati. Karena itu, untuk memberikan penjelasan kepada orang yang bodoh (tidak percaya), maka Paulus menggunakan beberapa perumpamaan (analogi) yang diambil dari pengalaman dan kenyataan alami yang ada dalam kehidupan sesehari.

\title{
Analogi Biji Menjelaskan Tubuh Kebangkitan (ay. 36-44a)
}

\author{
Pada bagian berikutnya, dalam ayat 36 tertulis: “... su 0
} sprireij ou zwopoleitai ean mh apoqanh. Istilah zwopoleitai (verb. indic. prest. pass. 3 pers. sing.) dalam bentuk present indicatif pasif berarti sedang dihidupkan. ${ }^{6}$ Terjemahan yang tepat dari kalimat di atas adalah “... apa yang engkau tabur tidak sedang dihidupkan terkecuali mati.” Kalimat ini menjelaskan aktivitas Allah yang memberikan kehidupan baru bagi biji tersebut. Paulus memberikan penjelasan dengan menggunakan perumpamaan tentang biji dari tumbuhtumbuhan (ay. 37). Biji (kokkon: acc. sing. mas.) adalah biji tanpa kulit yang bisa dijadikan benih tanaman. ${ }^{7}$ Biji yang ditaburkan orang ke tanah tersebut, tidak akan mendapatkan kehidupan yang baru, terkecuali biji tersebut mati terlebih dahulu. Karena biji yang ditanam ke dalam tanah akan mati, dan akan memperoleh kehidupan yang baru, yang lebih kaya dan lebih baik daripada sebelumnya. Lebih jelas, bahwa biji yang ditanam ke dalam tanah akan mengalami kematian terlebih dahulu, kemudian biji tersebut dihidupkan kembali oleh Allah dengan memberikannya suatu tubuh yang baru, yaitu tubuh dari tubuhnya sendiri (biji tersebut). Gambaran mengenai benih ini dipergunakan oleh Paulus untuk menunjuk pada janji kehidupan yang baru setelah kematian (bnd. Mat 13:31,32).

\footnotetext{
${ }^{4}$ Wesley J. Perschbecher, Refresh Your Greek (Chicago: Moody Press, 1989), 660

${ }^{5}$ Pfitzner, Ibid., 316

${ }^{6}$ Istilah zwopoleitai berasal dari kata zwopolew artinya to make alive, give life; Perschbacher, Ibid

${ }^{7}$ Kata kokkon: seed, grain; Perschbacher, Refresh Your.., 660
} 
Gambaran tentang benih yang mati terlebih dahulu, kemudian hidup (bertunas) lagi dengan tubuh yang baru yaitu tubuh yang diberikan kepada benih tersebut. Analogi biji ini dipakai Paulus untuk memberikan penjelasan tentang tubuh orang mati yang kepadanya Allah memberi suatu tubuh yang baru. Tubuh yang baru ini, bukan tidak terkait dengan tubuh yang mati, ada keterkaitannya. Yang jelas, Allah yang memberikan tubuh, seperti yang dikehendaki-Nya. Berkenaan dengan analogi tubuh tumbuhan dan tubuh manusia, Green berpendapat sebagai berikut:

Hidup baru, baik bagi tumbuh-tumbuhan maupun bagi manusia, tidak terjadi dengan sendirinya, tetapi sesuai dengan kehendak Allah dan ketetapan karya penciptaan-Nya. Tuhanlah yang 'memberikan' tubuh kepada tiap-tiap ciptaan-Nya, mulai dari tumbuh-tumbuhan sampai kepada manusia sendiri (lih. ay. 39 , dst.). ${ }^{8}$

Jadi, jelas bahwa hanya Allah saja yang dapat memberikan kehidupan yang baru bagi semua yang diciptakan-Nya, baik tubuh tumbuhan maupun tubuh manusia. Istilah didws in (verb. indic. prest. act. 3 pers. sing.) artinya memberi. ${ }^{9}$ Kata ini menjelaskan bahwa Allah-lah yang secara aktif berkarya dalam hal memberikan tubuh, dan karya-Nya ini belum berakhir, melainkan terus berlangsung. Dengan kata lain, karya Allah membangkitkan orang mati, dan memberi tubuh yang baru kepada mereka yang dibangkitkan, adalah belum berakhir.

Paulus meneruskan perumpamaan dengan menyebutkan keanekaragaman tubuh dan bentuk-bentuk yang luas darimana suatu kehidupan di dunia ini diwujudkan. Paulus menggunakan istilah swma dalam ayat 38. Istilah ini menjelaskan mengenai tubuh secara keseluruhan dan dapat diterapkan secara luas berkenaan dengan tubuh/badan, jasmani. ${ }^{10}$ Dalam bagian ini, Paulus menggunakan istilah lain, yaitu sarx (ay. 39) artinya daging, yaitu menjelaskan mengenai kepelbagaian daging (sarx, bahwa tidak semua daging adalah sama. Daging manusia, binatang, burung dan ikan adalah berbeda. ${ }^{11}$

Selanjutnya, Paulus menjelaskan perumpamaan lain mengenai perbedaan antara tubuh sorgawi dan tubuh duniawi. Paulus menggunakan istilah swmata (noun. nom. neut. pl.) artinya tubuh, yaitu menjelaskan mengenai keseluruhan tubuh manusia. Dimana antara tubuh sorgawi dan

\footnotetext{
${ }^{8}$ Green, Tafsiran Surat..., 108

${ }^{9}$ Kata didwsin artinya gives; Friberg, Analytical Greek New..., 545

10 James Strongs, Strong Exhaustive Concordance of the Bible (New York: Thomas Nelson Publishers, 1979), 70

${ }^{11}$ Ibid., 64
} 
tubuh duniawi memiliki kemuliaannya masing-masing (ay. 40). ${ }^{12}$ Kata kemuliaan disini menjelaskan ciri khas yang berbeda dari masing-masing tubuh, yaitu tubuh sorgawi dan tubuh duniawi. Adapun perbedaan kemuliaan yang dimaksudkan disini dijelaskan lebih jelas oleh Paulus, bahwa kemuliaan matahari lain dari kemuliaan bulan, dan kemuliaan bulan lain dari kemuliaan binatang. Demikian pula kemuliaan binatang yang satu berbeda dengan kemuliaan binatang yang lainnya (ay. 41). Perbedaanperbedaan di atas adalah menerangkan mengenai kemuliaan Pencipta-Nya, yaitu Allah yang berkuasa membentuk sesuai dengan kehendak-Nya.

Dalam ayat 42-44a, Paulus menjelaskan sesuatu yang bertolak belakang, yaitu mengenai kebangkitan orang mati, secara khusus mengenai tubuh kebangkitan. Tubuh untuk kehidupan dalam dunia ini disebut dengan tubuh alamiah, sedangkan tubuh untuk dunia yang akan datang disebut dengan tubuh rohaniah. Baik tubuh alamiah maupun tubuh dunia yang akan datang memiliki sifatnya sendiri-sendiri.

Dalan ayat 36-38, Paulus telah menjelaskan perumpamaan mengenai biji yang ditanam orang, maka biji tersebut akan mati terlebih dahulu, kemudian Allah akan menghidupkan kembali dengan tubuh yang baru. Demikian pula dengan kebangkitan orang mati (ay. 42). Orang yang telah mati akan ditaburkan (dikuburkan) dalam kebinasaan, maka tubuh orang mati tersebut akan membusuk dan hancur, karena tubuh tersebut bersifat alamiah. ${ }^{13}$ Kemudian tubuh itu akan dibangkitkan oleh Allah dengan tubuh yang baru, yang tidak akan binasa, tubuh yang mulia, karena tubuh tersebut bersifat rohaniah. Arti dari tubuh rohani menurut Farrar ialah: "suatu tubuh yang tidak berada di bawah kekuasaan dari keinginan jasmani atau dorongan nafsu dan rasio, melainkan sepenuhnya dikontrol oleh Roh. Karena itu, tidak memiliki keinginan atau kemampuan untuk memenuhi nafsu daging." 14 Penekanan Paulus dalam teks ini ialah karya Allah yang membangkitkan tubuh alamiah menjadi tubuh rohani. Lebih

12 Kata swmata berasal dari kata dasar swma artinya the body (as a sound whole), used in a very wide application, lit. or flg. : bodily, body, slave; Ibid., 70

${ }^{13}$ The mortal body, perishable (Gal 6:8), dishonored, humiliated because of sin (Phil 3:20,21), and weak (Mark 14:38) - a natural body like those of the animal worldand bring that body that "is sown" in death (John 12:24); W. Harold Mare, "ICorinthians" in The Expositor's Bible Commentary. Edited by Frank E. Gaebelein The Expositor's Bible Commentary (Grand Rapids, Michigan: Zondervan, 1976), 290

${ }^{14}$ The thing meant is a body which is not under the sway af corporeal desire or of intellectual and passionate impulses, but is wholly dominated by the Spirit, and therefore has no desire or capacity to fulfil the lusts of the flesh; F.W. Farrar, "I Corinthians" in The Pulpit Commentary. Vol. 19, edited by H.D.M. Spence (Grand Rapids, Michigan: Eerdmans, 1983), 491 
jauh lagi, berkenaan dengan itu, Martin berpendapat bahwa: "Allah yang menciptakan semua tubuh sorgawi yang banyak jumlahnya adalah Allah yang sama. Allah yang mampu menciptakan tubuh manusia dan memberikan kepada mereka suatu kemuliaan yang jauh melampaui imajinasi manusia." 15 Dengan kata lain, tubuh orang mati ditaburkan dalam kehinaan, namun tubuh itu akan dibangkitkan oleh Allah dengan cara menciptakan tubuh rohani, yang kepadanya akan diberikan kehormatan yang tidak tertandingi di dalam dunia ini, karena ia akan menjadi bagian dari kemuliaan Kristus sendiri (Flp 3:21; Kol 3:4). Tubuh orang mati ditaburkan dalam kelemahan yang merupakan cirikhas dari semua keberadaan manusia, tetapi dibangkitkan dalam kekuatan (ay. 43). Dalam hal ini, Paulus ingin menunjukkan kepada jemaat Korintus, bahwa orang Kristen akan ikut serta dibangkitkan bersama dengan Kristus, karena Ia pun disalibkan di dalam kelemahan tetapi dibangkitkan oleh kekuatan Allah (2Kor 13:4; Rm 1:4). Lebih lanjut dalam ayat 44a, Paulus menuliskan, bahwa yang ditaburkan adalah tubuh alamiah, yang dibangkitkan adalah tubuh rohaniah. Dalam pernyataan ini, Paulus menjelaskan adanya suatu kekontrasan, yaitu antara tubuh alamiah dan tubuh rohaniah.

\section{Perlunya Tubuh Rohaniah Dibandingkan Dengan Tubuh Jasmaniah} (ay. 44b-49)

Dalam ayat 44b tertulis bahwa "jika ada tubuh alamiah, maka ada tubuh rohaniah." Maksud dari tubuh alamiah adalah tubuh yang bedosa dan tidak hormat. Sedangkan tubuh rohaniah adalah tubuh yang tidak berdosa dan yang dihormati. Pandangan ini lebih luas diungkapkan oleh Sproul bahwa, Kekontrasan antara tubuh duniawi dan tubuh yang dibangkitkan jelas. Kekontrasan itu termasuk unsur-unsur di bawah ini:

Tubuh alamiah

Berdosa

Tidak hormat

Kelemahan

Alamiah
Tubuh yang dibangkitkan

Tidak berdosa

Mulia

Kekuatan

Spiritual

Berdosa, tidak hormat, dan kelemahan merupakan kualitas dengan mana kita terbiasa. Semua itu merupakan suatu bagian normal dari

${ }^{15}$ The God who made all these vast heavenly bodies is able to recreate human bodies and to give them a glory far beyond our imagining; Alfred Martin, First Corinthians (New Jersey: Loizeaux Brothers, 1989), 138-139 
pengalaman kita sehari-hari. Semua itu merupakan atribut-atribut tubuh alamiah kita. Kualitas-kualitas ini akan memberikan jalan dalam kebangkitan menuju antitesisnya. Tidak berdosa, kemuliaan, dan kekuatan merupakan sifat-sifat tubuh spiritual. ${ }^{16}$

Paulus disini telah menjelaskan mengenai perbedaan antara tubuh alamiah dan tubuh rohaniah. Keadaan tubuh alamiah sangatlah berbeda dengan tubuh rohaniah. Tubuh rohaniah adalah tubuh yang sudah dirubah dari pembatasan-pembatasan alamiahnya, yaitu tubuh yang dimuliakan, tubuh yang dibangkitkan dalam suatu dimensi baru. Sebagai fakta dari tubuh spiritual atau rohaniah adalah tubuh Tuhan Yesus yang dibangkitkan. Tubuh yang dimiliki Tuhan Yesus setelah kebangkitan-Nya adalah berbeda dengan tubuh Tuhan Yesus yang dikubur. Tubuh itu mewujudkan kesinambungan dan ketidaksinambungan. Kesinambungan dalam pengertian kesinambungan tubuh alamiah (waktu hidup sebagai manusia di dunia) dan tubuh sorgawi (tubuh yang telah diubah, yaitu tubuh kebangkitan, tubuh yang tidak dapat binasa, mulia dan bersifat rohani). Ketidaksinambungan yaitu sekalipun ada kesinambungan, namun ada juga perubahan atau perbedaan. Dalam hal ini, Paulus menekankan bahwa walaupun kita sudah mati, pasti akan mempertahankan kesinambungan dengan identitas-identitas kita yang sekarang, namun kita akan mengalami perubahan-perubahan bentuk. Sebagai contoh : Tuhan Yesus sarapan pagi bersama murid-murid-Nya, Tuhan Yesus memperlihatkan tanda-tanda penyaliban kepada Thomas (Yoh 20:27), Pintu terkunci, Yesus datang dan berdiri di tengah-tengah mereka (Yoh 20:26).

Paulus dalam ayat-ayat sebelumnya telah menjelaskan adanya perbedaan mengenai tubuh, yaitu tubuh alamiah dan tubuh rohaniah (ay. 36-44a). Dalam bagian ini (ay. 44b-49), Paulus menjawab pertanyaan mengenai: "Bagaimana orang mati dibangkitkan?," sebelum Paulus menjawab pertanyaan ini, Paulus mengawali jawabannya dengan memberikan suatu kesimpulan atas jawaban dari pertanyaan "jika ada tubuh alamiah, maka ada pula tubuh rohaniah" (ay. 44b). Dalam menjawab pertanyaan "Bagaimana orang mati dibangkitkan?" Paulus kembali memberikan suatu bukti yang kontras, yang diungkapkannya dalam ayat 45: Egeneto o prwtoj anqrwpoj Adam eij yuchn zwsan o escatoj Adam eij pneuma zwopoioun. NGSB menterjemahkan kalimat ini sebagai berikut: "Adam manusia pertama menjadi satu makhluk

${ }^{16}$ R.C. Sproul, Hai Maut Dimanakah Sengatmu? (Jakarta: BPK Gunung Mulia, 
yang hidup, Adam yang terakhir menjadi satu roh yang menghidupkan."17 Berbeda dengan terjemahan LAI. Dengan mengutip dari Kitab Kejadian 2:7, Paulus menunjukkan bahwa "Tuhan Allah menciptakan manusia pertama dari debu tanah" (Adam berasal dari kata adamah dalam bahasa Ibrani artinya tanah)" dan menghembuskan nafas hidup ke dalam hidungnya, maka jadilah manusia pertama, yaitu Adam menjadi makhluk yang hidup atau jiwa yang hidup. Adam dengan tubuh jasmani atau alamiahnya "yang diberi jiwa" adalah kebalikan dari Adam yang terakhir, yaitu Adam yang memberi kehidupan (zwopoioun. acc. sing. neut. pres. act. part.). ${ }^{18}$ Adam yang terakhir (zwpoioun), yang dimaksudkan oleh Paulus adalah Kristus yang memberi hidup rohani (bnd. Yoh 6:63). Kristus yang memberi hidup pada diri-Nya sendiri. Lebih lanjut ayat 46, Paulus menjelaskan bahwa yang mula-mula datang bukanlah yang rohaniah, tetapi yang alamiah; kemudian barulah datang yang rohaniah. Dalam hal ini, Paulus menyatakan bahwa manusia pertama adalah seperti Adam pertama, yaitu bersifat alamiah, namun setelah manusia menerima atau percaya Kristus secara baru maka akan diberinya suatu tubuh yang baru yaitu tubuh rohaniah. Selanjutnya Paulus memberikan penjelasan lebih rinci, bahwa manusia pertama yaitu Adam yang diciptakan Allah dari debu tanah (Kej 2:7), bersifat jasmani atau dapat rusak dan binasa. Tetapi manusia kedua adalah berasal dari sorga, dimana sebelum menjadi manusia, Dia bersifat kekal dan mulia, yang kemudian diterimanya kembali secara nyata sesudah Dia dibangkitkan dari antara orang mati (ay. 47). Hal yang sama juga diungkapkan lebih luas lagi oleh Pfitzner sebagai berikut:

Seluruh manusia adalah dari debu tanah dan bersifat jasmani, seperti halnya manusia kedua berasal dari debu tanah dan bersifat jasmani. Di pihak lain, semua yang tergolong kepada Kristus sebagai manusia yang berasal dari sorga, setelah kebangkitan pada kedatangan-Nya yang kedua kali, akan berasal dari sorga; tubuh duniawi yang lama akan ditukar dengan tubuh sorgawi. ${ }^{19}$

${ }^{17}$ Living being ... life-giving spirit. Paul clarifies his meaning by continuiting the contrast between the first and the last Adam (21,22 note). The Greek word translated "being" (psyche) is related to the word translated "natural" in v. 44 (psychikos). The word "life-giving spirit" are most probably a reference to the Holly Spirit. ......, New Geneva Study Bible ..., 1823. "The first man Adam became a living being, the last Adam became a life giving spirit."

${ }^{18}$ Istilah zwopoioun berasal dari kata zwopoiew artinya to make alive, give life. Attributive pert dari pneuma; Perschbacher, Refresh Your..., 661

${ }^{19}$ Pfitzner, Kesatuan Dalam Kepelbagaian ..., 321 
Semua yang pernah hidup, mula-mula memakai rupa yang alamiah. Dengan kata lain semua keturunan Adam membawa citranya (Kej 5:3). Setelah orang percaya mengalami kebangkitan, maka orang percaya akan memakai rupa sorgawi, yaitu tubuh yang mulia, tidak binasa seperti tubuh Kristus (Flp 3:21). Bagi mereka (orang Kristen) yang memiliki hubungan dengan Kristus, yang sekarang masih hidup dalam tubuh alamiah, namun mereka sudah memiliki hidup sorgawi. Oleh karena itu pada akhirnya juga akan mengenakan rupa sorgawi atau tubuh rohaniah (ay. 48-49).

\section{Alasan Pengubahan Tubuh Saat Kebangkitan (av. 50-58)}

Paulus sebelum menjawab pertanyaan-pertanyaan berikutnya yang berhubungan dengan waktu kebangkitan, ia mengawali jawabannya dengan menyebutkan dua hal dalam ayat 50, yaitu: Pertama: Darah dan daging tidak mendapat bagian dalam Kerajaan Allah. Kedua: yang binasa tidak mendapat bagian dalam apa yang tidak binasa. Pernyataan Paulus ini adalah kalimat yang paralel, dimana Paulus menyatakan bahwa orang yang masih hidup, tidak akan masuk ke surga. Ungkapan "darah dan daging" diterangkan oleh ungkapan "yang binasa." Maksudnya ialah tubuh manusia yang masih hidup adalah tubuh yang dapat binasa, tidak kekal, tidak mungkin mendapat bagian dalam kekekalan. Paulus menekankan bahwa manusia sesuai dengan sifat alamiahnya, tidak dapat menjadi bagian dari kerajaan Allah tanpa karya pembaharuan Roh yang mengubahkan. Lebih jelas lagi, Pernyataan Paulus yang kedua tadi adalah merupakan pelengkap namun ada sedikit perbedaan, yang binasa tidak mendapat bagian dalam apa yang tidak binasa (ay. 42). Yang dimaksudkan oleh Paulus disini adalah tubuh yang mati tidak mempunyai klaim yang alamiah terhadap Kerajaan Allah. Dengan kata lain bahwa tubuh jasmani (yang binasa) tidak dapat mengklaim kekekalan.

Dalam ayat 51-56 Paulus mengemukakan suatu penjelasan untuk menjawab pertanyaan yang mungkin muncul. Pertanyaan tersebut adalah berhubungan dengan waktu kebangkitan. Kebangkitan ini terjadi pada waktu kedatangan Tuhan Yesus yang kedua kali (Parousia). Inilah yang dikatakan oleh Paulus "sesungguhnya aku menyatakan kepadamu suatu rahasia" (ay. 51a). Rahasia yang diungkapkan oleh Paulus adalah rahasia yang diterimanya dari Allah bahwa "kita tidak akan mati semuanya, tetapi kita semuanya akan diubah. Artinya bahwa, ada orang yang masih hidup, pada saat kebangkitan orang mati, yang terjadi secara simultan dengan kedatangan Tuhan Yesus yang kedua kali (bnd. 1Tes 4:15), maka orang 
yang masih hidup pada waktu Tuhan Yesus datang yang kedua kali akan mengalami perubahan, yaitu pada saat nafiri terakhir berbunyi, mereka akan diubah dalam sekejap mata, tanpa harus mengalami kematian terlebih dahulu (ay. 51b-52). Ungkapan "dalam sekajap mata (en riph ofqalmou) merupakan ungkapan yang menjelaskan mengenai kejadian yang tidak dapat dijangkau oleh kasat mata. Karena istilah riph berarti "gerakan yang cepat, kilasan, kelap-kelip." ${ }^{20}$ Istilah tersebut terkait dengan kata ofqalmou (mata), sehingga yang dimaksud dengan ungkapan sekejap mata ialah perubahan yang terjadi dalam waktu yang cepat sekali, seperti kedipan mata, atau kelipan cahaya. Hal ini menekankan tentang hakekat yang intensitas dari transformasi tubuh manusia pada waktu kebangkitan yang terjadi pada saat kedatangan Tuhan Yesus kedua kali (parousia) ${ }^{21}$ Perubahan sekejap yang terjadi pada orang yang masih hidup adalah terjadi pada saat kedatangan Tuhan Yesus yang kedua kali. Hal ini dimengerti dengan ungkapan "pada waktu bunyi nafiri yang terakhir," yang menandai pengumuman suatu kejadian tentang kesudahan atau kejadian "yang terjadi" dalam sejarah dunia (bnd. Mat 24:31; 1Tes 4:16).

Orang Kristen yang sudah mati, pada saat kedatangan Tuhan Yesus yang kedua kali, yaitu pada saat nafiri berbunyi, mereka akan dibangkitkan "dalam keadaan yang tidak dapat binasa," orang Kristen yang masih hidup akan "diubah dalam sekejap mata" dan mereka bersama-sama akan berjumpa dengan Tuhan (1Tes 4:17).

Pada ayat 53-57 merupakan alasan yang mendasar mengenai perubahan yang terjadi pada saat kebangkitan. Dalam ayat 53, Paulus mengulangi perlunya tubuh alamiah diubah menjadi tubuh rohaniah pada saat kebangkitan (ay. 50). Orang-orang percaya yang masih hidup dan yang sudah mati pada waktu Kristus datang kembali "Yang dapat binasa ... harus mengenakan yang tidak dapat binasa." Yang dapat binasa berarti tubuh jasmani, pada saat kebangkitan akan mengenakan (endusasqai: to dress) citra atau bentuk yang tidak dapat mati (ay. 49). Pfitzner mengungkapkan mengenai perubahan yang besar ini secara lengkap, bahwa:

${ }^{20}$ Riph throwing, rapid movement, e.g. of the eyes; the 'casting' of a glance takes an extremely short time: en riph ofqalmon in the twinkling of an eye I Cor 15; Arndt, A Greek-English Lexicon..., 736

${ }^{21} \mathrm{Gk}$. en riph ofqalmou, the equivalent of the Eng. "the blink of an eye". It is of interest that this physical phenomenen was picked up in more that one culture to express the speed with which something can happen; Gordon D. Fee, The New International Commentary On The New Testament (Grand Rapids, Michigan: Eerdmans, 1987), 801 
Jiwa kita yang tidak dapat binasa" akan mewarisi tubuh yang tidak dapat binasa. Sebaliknya, tubuh yang dapat binasa ini harus mengenakan yang tidak dapat binasa, tubuh yang tidak lagi terancam oleh maut. Acuan kepada orang-orang percaya yang sudah mati dan orang-orang percaya yang masih hidup pada waktu kedatangan Kristus kembali jelas dilanjutkan dalam kata-kata ini. Meskipun yang masih hidup mempunyai tubuh yang fana, yang telah ditetapkan untuk mati, ia pun akan diubahkan untuk ikut serta di dalam kehidupan Allah; Dialah satu-satunya yang memiliki kekekalan (1Tim 6:16). "Yang fana" akan "ditelan oleh hidup (2Kor $5: 4) .{ }^{22}$

Paulus menjelaskan bahwa, adanya keharusan suatu perubahan bagi umat Tuhan yang hidup maupun yang sudah mati, yaitu akan mengalami perubahan dari tubuh yang alamiah menjadi tubuh yang rohaniah. Peristiwa ini terjadi pada saat kebangkitan, yaitu saat dimana Tuhan Yesus datang kembali (ay. 53-54a).

Dalam ayat 53-54a Paulus telah menggambarkan istilah-istilah yang kontras mengenai suatu perubahan di masa depan pada waktu kebangkitan yaitu pada saat kedatangan Tuhan Yesus kembali. Sedangkan dalam 54-57, paulus membahas mengenai dua teks dalam PL untuk menyimpulkan pemikiran sebelumnya, dan untuk membentuk sebuah nyanyiankemenangan yang menantang maut sebagai sebuah kuasa yang bagi orang Kristen sudah dikalahkan. Disini Paulus mengutip, pertama: Yesaya 25:8 "Ia akan meniadakan maut untuk seterusnya". Kata-kata Paulus "maut telah ditelan dalam kemenangan (ay. 54b)." Kedua: Hozea 13:14 dalam bahasa Ibrani menyatakan: "Dimanakah penyakit samparmu, hai maut, dimanakah tenaga pembinasaanmu, hai dunia orang mati?", Paulus dalam 1Korintus 15:55 menyatakan: "Hai maut dimanakah kemenanganmu (ni koj: victory)? Hai maut dimanakah sengatmu (kentron: sting)?" Teks PL di atas, dipakai oleh Paulus untuk menggaris bawahi hubungan antara kebangkitan dan pemberian tubuh rohaniah dengan kemenangan terakhir dari maut, artinya Tuhan Yesus akan membinasakan kematian dan alam maut, dimana kemenangan-Nya meliputi dua hal, yaitu kebangkitan orang percaya yang mati di dalam iman kepada Kristus dan perubahan orang-orang percaya yang masih hidup pada waktu kedatangan Tuhan Yesus. Dalam hal ini Paulus berkata bahwa yang dinubuatkan oleh nabi Yesaya dan nabi Hozea adalah benar dan tidak dapat ditolak lagi. Kemudian Paulus menerangkan hal itu lebih jelas dalam ayat selanjutnya, yaitu ayat 56-57. Dituliskan

${ }^{22}$ Pfitzner, Kesatuan Dalam Kepelbagaian ..., 325-326 
dalam ayat 56 "sengat maut ialah dosa dan kuasa dosa ialah Hukum Taurat." Paulus mau menjelaskan bahwa saat ini maut masih bekerja dan memiliki sengatnya, yaitu dosa yang menyerang manusia melalui pelanggaran-pelanggaran terhadap Hukum Taurat. Dalam hal ini kalau manusia percaya kepada Kristus maka dosa dihapuskan, dan akan mendapat kebebasan dari akibat dosa (maut), dimana tubuh yang binasa diubah menjadi tubuh yang tidak dapat binasa pada waktu kebangkitan. Dengan kata lain mereka akan dibangkitkan dengan tubuh yang "tidak dapat binasa... dan tidak dapat mati." Dengan demikian "maut telah ditelan dalam kemenangan" atau maut tidak berkuasa lagi atas manusia yang dosanya telah dibereskan sehingga ia dibangkitkan untuk dapat menikmati hidup kekal. Grosheide menjelaskan hubungan antara dosa dan Hukum Taurat adalah sebagai berikut:

Kuasa dosa adalah hukum Taurat: Bukan hanya kematian tetapi juga dosa digambarkan sebagai suatu kuasa yang mempertahankan dirinya sendiri. Dosa menggunakan hukum Taurat yang mengstimulasi orang yang telah jatuh dalam dosa untuk berbuat dosa ( $\mathrm{Rm}$ 5:12, 7:7). Paulus berbicara mengenai kemenangan yang terbesar, bahwa kemenangan bukanlah pada masa kini, yaitu ketika orang diselamatkan, melainkan setelah segala sesuatu ditaklukkan sejak dosa Adam dihapuskan dan setelah setiap kuasa yang menentang Allah dilenyapkan. ${ }^{23}$

Dosa menggunakan Hukum Taurat yang mengstimulasi manusia untuk berbuat dosa, namun bagi orang yang percaya, kuasa dosa tidak menguasainya lagi, karena orang percaya telah mengalami kemenangan atas dosa dan maut melalui iman. Selanjutnya dalam ayat 57, Paulus menjelaskan bahwa oleh karya Kristus telah memuaskan apa yang menjadi tuntutan Hukum Taurat (bnd. Gal 3:13). Kuasa dosa telah dihancurkan, sehingga sekarang orang percaya dapat "bersyukur kepada Allah" Kemenangan orang percaya atas dosa dan maut telah diterima melalui iman kepada Yesus Kristus. Hal ini pun diungkapkan lebih luas oleh Pfitzner, sebagai berikut:

${ }^{23}$ The power of sin is the law: not only death but sin also is described as a power that seeks to maintain itself. Sin uses the law which stimulates fallen man to sin (cf. Rom. 5:12; 7:7f). Paul speak of the ultimate victory; that victory is not present when some men are saved, but only after everything that had assumed dominion since Adam's sin has been abolished and after every God-opposing power has been annihilated; F.W. Grosheide, Commentary On The First Epistle To The Corinthians (Grand Rapids, Michigan: Eerdmans, 1960), 394 
Yesus Kristus yang oleh Injil telah mematahkan kuasa maut dan mendatangkan hidup yang tidak dapat binasa" (2Tim 1:10). Seperti dalam Roma 7:25, Paulus memisahkan diri dari kisah yang menyedihkan tentang perhambaan manusia untuk mengucapkan doa syukur: Syukur kepada Allah, telah memberikan kepada kita kemenangan oleh Yesus Kristus, Tuhan kita. Mereka yang hidup dengan kasih karunia dan tidak lagi hidup di bawah keputusan Taurat yang menghukum, bebas dari tirani maut - termasuk rasa takut akan maut (Rm 6:14; 8:1,2; Ibr 2:14,15). Kematian fisik masih harus ditanggung, tetapi bahkan itu pun tidak dapat merampas dari kita kepasti akan kemenangan di dalam Kristus di masa datang ( $\mathrm{Rm}$ 8:37-39). Mereka yang berada di dalam Kristus telah mati kepada dosa (dengan ikut serta di dalam kematian-Nya yang sempurna dalam baptisan); jadi, merekapun ikut serta di dalam kehidupan-Nya yang baru, kehidupan yang akan disempurnakan pada hari kebangkitan (Rm 6:1-11). Tetapi kemenangan selalu adalah milik Kristus, tak pernah milik kita - meskipun Ia dengan kasih karuniaNya memungkinkan kita ikut serta di dalam arak-arakan kemenangan bahkan sejak di dalam kehidupan ini (2Kor 2:14). ${ }^{24}$

\section{IMPLIKASI BIBLIOLOGIS, SOTERIOLOGIS, EKKLESIOLOGIS DAN ESKATOLOGIS DOKTRIN KEBANGKITAN ORANG MATI/TUBUH}

Bertolak dari penelitian teks 1Korintus 15:1-58, paling sedikit penulis menemukan 4 implikasi. Di bawah ini, akan penulis uraikan satu persatu implikasi tersebut.

\section{Implikasi Bibliologis (1Kor 15:5,7-10)}

Kata bibliologis dari kata biblio yang artinya buku atau Kitab, sedangkan bibliologis yaitu berhubungan dengan penyelidikan bahasa, penyelidikan keadaan zaman tertulisnya Kitab-kitab yang membentuk Kitab Suci yang sedekat-dekatnya dengan yang asli dan tafsiran yang mencari dan menerangkan Kitab Suci. ${ }^{25}$

Kebenaran mengenai kebangkitan diawali oleh Paulus dengan mengemukakan alasan bibliologis, yang dikemukakannya pada ayat 3 dan

\footnotetext{
${ }^{24}$ Pfitzner, Kesatuan dalam Kepelbagaian ..., 327-328

${ }^{25}$ R. Sudarmo, Ikhtisar Dogmatika (Jakarta: BPK Gunung Mulia, 1986), 18
} 
4, bahwa baik kematian Tuhan Yesus maupun kebangkitan-Nya adalah terjadi sesuai dengan Kitab Suci. Paulus menyatakan: “... sesuai dengan Kitab Suci, ... sesuai dengan Kitab Suci." Dua kali Paulus menekankan kebenaran dengan kalimat "Sesuai dengan Kitab Suci". Inilah implikasi bibliologis dari kebangkitan Tuhan Yesus. Kebenaran Kitab Suci digenapi dengan peristiwa Kebangkitan Tuhan Yesus. Selanjutnya kebenaran Kitab Suci dan peristiwa kebangkitan Yesus diperkuat dengan kesaksian para murid mengenai penampakan Tuhan Yesus kepada mereka. Penampakkan Diri Tuhan Yesus kepada para murid merupakan salah satu ketentuan yang mendasar dimana para murid disebut Rasul. Karena para murid telah melihat Tuhan Yesus yang telah bangkit dan Rasul-Rasul inilah yang telah menulis Injil-Injil. Salah satu argumentasi Paulus mengenai kebenaran Injil, berita kebangkitan Yesus, adalah dengan penampakan Tuhan Yesus yang bangkit kepada murid-murid. Mereka kemudian disebut rasul karena alasan telah melihat Tuhan Yesus secara langsung. Paulus mengemukakan sejumlah laporan tentang penampakan Tuhan Yesus kepada murid-murid. Dalam ayat 5, 7-10: Pertama: Kristus menampakkan diri-Nya kepada Kefas atau Petrus dan kepada keduabelas murid (bukan mitos). Kedua: Kristus menampakkan diri-Nya kepada lebih dari lima ratus saudara. Ketiga: Kristus menampakkan diri-Nya kepada Yakobus, kemudian kepada semua rasul. keempat; Kristus menampakkan diri-Nya kepada Paulus sendiri, waktu penglihatan Paulus saat perjalanannya ke Damsyik, dengan maksud untuk menganiaya orang Kristen (Kis 9). ${ }^{26}$ Peristiwa inilah yang digambarkan oleh Paulus "seperti anak yang lahir sebelum waktunya", artinya Paulus mengungkapkan mengenai dirinya yang tidak layak, namun dilayakan oleh Tuhan Yesus yang datang menampakan Diri-Nya kepadanya. ${ }^{27}$ Kesaksian Paulus ini, diperkuat dengan pengalaman dirinya sendiri. Paulus bersaksi dalam kerendahan hatinya dan ia senantiasa merasa menyesal karena telah menganiaya jemaat Tuhan (ay. 9-10). Alasan inilah yang dianggap Paulus bahwa dirinya adalah yang terkecil (paling hina)

\footnotetext{
${ }^{26}$ Green, Tafsiran Surat I..., 102

${ }^{27}$ Ungkapan itu bukan menunjuk kepada saatnya Paulus bertobat, melainkan kepada tindakan menyela yang mendadak, yang dengannya ia disobek, dari menentang Tuhan menjadi murid Tuhan atau kepada perasaannya sebagai orang yang tak layak sama sekali - sama tak layak disebut rasul, sama halnya abortus dipandang sebagai dewasa. Sekalipun disini Paulus menyebut dirinya yang paling hina dari semua rasul, ia tidak bermaksud menunjukkan bahwa pelayanannya lebih rendah daripada pelayanan rasul-rasul lainnya (bnd. 2Kor 11:5; Gal 2:11), sebab sebenarnya ia bekerja lebih berkelimpahan, tapi karena ia telah menganiaya jemaat Allah (Kis 26:9 dsb. Gal 1:13) ia tak patut sama sekali disebut rasul (1Tim 1:15); Donald Guthrie, Tafsiran Alkitab Masa Kini. 3 (Jakarta: BPK Gunung Mulia, 1992), 530-531
} 
diantara semua rasul. Namun, kuasa kebangkitan Kristus telah merubah Paulus secara total menjadi seorang yang sungguh-sungguh hidup dan melayani Tuhan. Pfitzner juga menyatakan hal yang sama. ${ }^{28}$ Kuasa yang mengubah hidup Paulus ini, disadari olehnya sebagai karunia Allah (ay. 10). Semua laporan mengenai penampakan Tuhan Yesus kepada muridmurid, termasuk kepada Paulus memberikan kesaksian yang kuat bahwa kebangkitan Yesus adalah berita yang benar, dan historis, bukan mitos.

\section{Implikasi Soteriologis (1Kor 15: 17-19; 21, 24-25, 27-28)}

Kata soteriologis dari kata dasar soter artinya selamat. Kata soteriologis adalah berkaitan dengan berkat keselamatan kepada orang berdosa dan pembaharuan yang dialaminya untuk hidup dalam persekutuan yang intim dengan Allah. ${ }^{29}$ Jadi, yang dimaksud dengan implikasi soteriologis adalah kebangkitan Kristus menjadi dasar bagi Gereja atau orang percaya diselamatkan.

Dalam ayat 17, Paulus menekankan suatu akibat apabila Kristus tidak dibangkitkan. Tanpa kebangkitan Kristus maka kepercayaan mereka menjadi sia-sia, tidak berguna dan tetap hidup dalam dosa mereka. Ayat 18, Paulus menekankan, jika Kristus tidak mati, maka sebagai akibat yang berikutnya adalah jemaat Korintus yang percaya dan mati dalam Kristus mengalami kebinasaan. Lebih dalam lagi Paulus menyatakan bahwa: "Jikalau kita hanya dalam hidup ini saja berharap pada Kristus, maka kita adalah orang-orang yang paling sengsara dari segala manusia (ay. 19)." Dalam ungkapan ini, Paulus menyatakan betapa malang atau sengsaranya jemaat Korintus yang telah berharap pada Kristus dalam seluruh kehidupannya, termasuk kehidupan setelah kematian, Pernyataan Paulus ini adalah sebagai akibat jikalau Kristus tidak dibangkitkan. Dalam hal ini, jemaat Korintus berharap pada Allah yang tidak berkuasa untuk menyelamatkan, karena itulah Paulus menyatakan bahwa mereka adalah orang yang sengsara atau malang dari segala manusia. Lebih jauh dari itu, tanpa kebangkitan Kristus, maka, iman jemaat Korintus adalah iman yang

28 Tuhan menangkap penganiaya besar ini dan mengubahnya menjadi seorang misionaris yang besar (Gal 1:13-16). Hal itu, kata Paulus, hanya membuktikan satu hal : karena kasih karunia Allah aku adalah sebagaimana aku ada sekarang; Pfitzner, Kesatuan dalam Kepelbagaian..., 295

${ }^{29}$ Louis Berkhof, Teologi Sistematika, 4: Doktrin Keselamatan (Surabaya: Momentum, 2002), 5 
kosong, karena mereka percaya kepada Injil yang tidak benar dan sia-sia. Maka orang Kristen tidak lebih dari orang-orang bukan Kristen.

Kita telah mengetahui bahwa pengampunan merupakan satu kebutuhan kita yang paling mendasar, dan satu dari karunia Allah yang Agung. Menurut Alkitab pengampunan hanya mungkin bila ada darah (Mat 26:28; Rm 6:23). Dan dalam hal ini pengampunan terkait dengan perjanjian, darah merupakan adanya pengampunan dosa yang disyaratkan oleh pencurahan. Darah merupakan isi dari perjanjian. Kristus menggenapi dengan pencurahan di kayu salib bahkan mati di kayu salib. Dan kebangkitan membuktikan bahwa darah Kristus atau kematian-Nya di kayu salib adalah sebagai bukti bahwa karya pengampunan dosa itu sempurna dan berkenan kepada Allah. Karena itu Paulus dalam 1Korintus 15 menekankan mengenai pentingnya kebangkitan bagi pengampunan dosa, sebagaimana pendapat Stott sebagai berikut:

Kristus telah dibangkitkan dari antara orang mati dan melalui membangkitkan-Nya, Allah telah memberikan jaminan kepada kita bahwa Ia mengakui kematian yang berkaitan dengan dosanya, bahwa Ia tidak mati sia-sia dan bahwa mereka yang percaya kepadaNya menerima suatu pengampunan yang penuh dan bebas. Kebangkitan mengsyahkan salib Kristus. ${ }^{30}$

Jadi, kebangkitan memiliki implikasi untuk orang Kristen dan juga untuk Kristus. Satu sisi kebangkitan memungkinkan kesatuan orang percaya dengan Kristus. Kristus sebagai kepala orang percaya dan orang percaya sebagai tubuh Kristus. Hal ini menerangkan mengenai Kristus yang hidup dalam kehidupan orang percaya. Pemaparan tersebut, dipertegas dalam ayat 2, yang mengungkapkan bahwa Kristus adalah satu-satunya jaminan keselamatan. Jadi jelaslah bahwa, Kristus telah dibangkitkan. Dia adalah sebagai perintis atau buah sulung dari kebangkitan orang mati, yang mana mengakibatkan kebangkitan bagi orang percaya pada hari kedatangan-Nya. "Kemudian tiba kesudahannya... (ay. 24)." Sesudah kedatangan Kristus dan orang percaya yang telah mati dibangkitkan, maka tibalah kesudahannya, yaitu puncak dari segala zaman. Kedatangan Kristus adalah untuk meneguhkan kedaulatan-Nya yang penuh dan secara langsung

${ }^{30}$ The terrible consequences of no resurrection would be that the apostles are false witnesses, believers are unforgiven, and the Christian dead have been perished. But in fact, Paul continued, Christ was raised from the dead, and by raising him God has assured us that he approves of his-bearing death, that he had not died in vain, and that those who trust in him receive a full and free forgiveness. The resurrection validates the cross; John Stott, The Contemporary Christian (Leicester: Inter Versity Press, 1992), 82 
(2Tes 1:7). Sebelum Kristus meneguhkan kedaulatan-Nya, tiap kuasa yang menentangNya akan dibinasakan. Setelah semuanya dibinasakan, yaitu tugas yang diberikan Allah Bapa telah dipenuhi (Mat 28:18), maka Kristus menyerahkan kedaulatan atau kerajaan-Nya kembali kepada Allah Bapa (1Kor 15:24). Kerajaan yang diserahkan Kristus kepada Allah Bapa bukanlah pemerintahan atas daerah atau wilayah tertentu secara lahiriah, melainkan yang diserahkan Kristus adalah kekuasaan penuh atas segala sesuatu termasuk manusia (bnd. Flp 2:10). Untuk itu, terlebih dahulu Dia harus membinasakan segala kekuasaan lain. ${ }^{31}$ Karena itulah Kristus harus memegang pemerintahan sebagai Raja (ay. 25), sampai pemerintahan yang lain dibinasakan dan ditaklukkan, yaitu sebelum kesudahannya tiba. Hal ini adalah sesuai dengan janji Allah bahwa Kristus akan memperoleh kemenangan terakhir atas kuasa-kuasa yang menentang-Nya (bnd. Mzm 110:1). Jadi jelas, Paulus mau menjelaskan bahwa kuasa lain yang paling terakhir dihapuskan atau dibinasakan oleh Kristus adalah maut. Setelah itu tidak ada lagi yang harus dihapuskan, karena maut merupakan musuh paling terakhir dari kuasa-kuasa lain yang dibinasakan oleh Kristus. Dalam ayat 27-28, Paulus berbicara tentang manusia yang sempurna, yaitu Yesus Kristus. Segala sesuatu telah ditaklukkan di bawah kaki-Nya, Allah Bapa yang menyerahkan kekuasaan mutlak itu kepada Kristus. Kalau pekerjaan yang diberikan Allah Bapa kepada Kristus telah selesai, maka Kristus akan menyerahkannya kembali segala kekuasaan kepada Bapa-Nya (ay. 24). Sebagai bukti bahwa kepada-Nya Anak sendiri ditaklukkan, yaitu Anak taat kepada Bapa-Nya. Tujuannya adalah Allah Bapa menjadi semua di dalam semua (bnd. Rm 11:3).

\section{Implikasi Ekklesiologis (1Kor 14:26-40; 16:1-4)}

Ekklesia merupakan kata dasar dari ekklesiologi. Kata ekklesia berasal dari dua kata: -ek dan kaleo, yang artinya memanggil keluar. ${ }^{32}$ Gereja adalah sekumpulan orang-orang yang dipanggil atau orang percaya dan Tuhan sendiri yang memanggil mereka. ${ }^{33}$ Jadi, implikasi ekklesiologis yang dimaksudkan adalah kebangkitan Kristus menjadi sentral pemberitaan atau pengajaran dalam Gereja. Sehingga Gereja memiliki pemahaman yang benar tentang kebangkitan orang mati dan memiliki iman yang hidup serta

\footnotetext{
${ }^{31}$ Guthrie, Tafsiran Alkitab Masa ..., 532; Green, Tafsiran Surat I...,105

${ }^{32}$ R. Soedarmo, Iktisar Dogmatika (Jakarta: BPK Gunung Mulia, 1986), 172

${ }^{33}$ Luois Berkhof, Teologi Sistematika 5 (Surabaya: Momentum, 2003), 7
} 
Gereja dapat mengaplikasikanya dalam kehidupan bergereja. Ada beberapa implikasi ekklesiologis dalam 1Korintus 15, di antaranya sebagai berikut.

\section{Didaskalia (1Kor 15:1-2)}

Kata didaskalia berasal dari bahasa Yunani didasco yang artinya mengajar, sedangkan kata didaskalia adalah berhubungan dengan apa yang diajarkan. Kata didaskalia dapat disebut juga dengan kata doktrin (bahasa Latin). ${ }^{34}$ Jadi, yang dimaksudkan dengan implikasi bagi didaskalia Gereja adalah pengajaran atau doktrin kebangkitan Tuhan Yesus memastikkan atau menjamin pengajaran Kristen. Dengan kata lain, bahwa kebangkitan Kristus berimplikasi kepada kebenaran dan kepastian pengajaran Gereja, sehingga jemaat memiliki pemahaman, pengakuan yang benar tentang imannya dan memberikan diri dalam pengabdian kepada Kristus yang bangkit.

\section{Komitmen dan Pengabdian (1Kor 15:3, 58)}

Komitmen artinya perjanjian, dan kata pengabdian berasal dari kata dasar abdi yang artinya hamba. Sedangngkan pengabdian artinya proses, perbuatan atau cara mengabdi. Jadi, yang dimaksud dengan implikasi komitmen dan pengabdian adalah doktrin kebangkitan orang mati atau tubuh membuat Gereja atau orang percaya berkomitmen atau mengambil keputusan atau perjanjian untuk menjadi hamba atau alat di tangan Tuhan. Setelah Paulus menarik perhatian jemaat Korintus kepada Injil yang telah mereka terima, ia melanjutkan pembahasannya dengan menekankan hakekat Injil itu sendiri. Dalam ayat 3, ia menyatakan tentang Injil yang telah ia terima, yaitu tradisi pengajaran Gereja. ${ }^{35}$ Bahwa inti Injil adalah adalah berpusat pada kematian Kristus. "Salib itu merupakan inti dari Injil," menurut pernyataan Morris. ${ }^{36}$ Wilson menyatakan: "Karena dosa-dosa kita yang merupakan alasan kematian Kristus, ini berarti bahwa Ia mati sebagai orang berdosa, sebagai kurban penggantian yang oleh-Nya kita menerima pengampunan dosa-dosa." ${ }^{37}$ Makna kematian Kristus disampaikan Paulus,

\footnotetext{
${ }^{34}$ www.wikipedia.com
}

${ }^{35}$ This is the kerygma, the proclamation the gospel preached by the early church; Morris, Tyndale New Testament..., 201

${ }^{36}$ The cross is at the heart of the Gospel; Ibid.

${ }^{37}$ Since 'our sins' were the only reason for Christ's death, this means that he died for as sinners, as the substitutionary sacrifice through whom we receive the forgiveness of 
dengan harapan akan menggugah kesadaran jemaat Korintus, supaya tidak cepat mengikuti injil lain, yaitu injil yang tidak menghargai kematian dan kebangkitan Kristus. Sedangkan dalam ayat 58, Paulus menghimbau jemaat Korintus untuk berdiri teguh, jangan goyah, dan giat dalam pekerjaan Tuhan. Jadi, kebangkitan Kristus membuat orang percaya mengambil keputusan atau berjanji mengikut Kristus dan mengabdikan dirinya untuk dipakai menjadi alat-Nya dalam memberitakan Injil.

\section{Evangelistik atau Pemberitaan Injil (1Kor 15: 57-58)}

Paulus dalam ayat 57 menyatakan bahwa kemenangan orang percaya atas dosa dan maut telah diterima melalui iman kepada Kristus. Oleh karena itu ayat 58 Paulus menghimbau jemaat Korintus untuk berdiri teguh, tidak goyah dan giat selalu dalam pekerjaan Tuhan. Ajakan Paulus ini dari pengalaman dan hidupnya sendiri. Ia giat melayani Tuhan, karena tahu adanya kebangkitan orang percaya. Ia sungguh-sungguh bekerja keras. Hal ini ia lakukan karena adanya pengharapan akan kebangkitan orang percaya dan ia dapat bekerja keras dalam melayani Tuhan, semata-mata hanyalah oleh kasih karunia Allah. Kebangkitan Kristus merupakan dasar kebangkitan orang percaya. Injil menyatakan bahwa setelah Kristus bangkit dari kematian, Dia memberi amanat misi kepada para murid.

\section{Kesalehan Kristen (1Kor 15:20, 58)}

Paulus dalam ayat 20 "...yang benar ialah Kristus telah dibangkitkan dari antara orang mati, sebagai yang sulung dari orang-orang yang telah meninggal." Kristus telah bangkit, hal ini menjelaskan mengenai suatu kejadian yang sudah berlangsung. Dengan kebangkitan Kristus ini, membuat iman jemaat diteguhkan. Jadi, dengan kebangkitan Kristus, Allah menyatakan pengampunan, dan Allah juga menjamin kehidupan bagi jemaat selanjutnya. Stott mengungkapkan bahwa: "Kebangkitan Yesus memberikan jaminan kepada kita mengenai pengampunan Allah. Kita telah mengetahui bahwa pengampunan adalah salah satu kebutuhan yang paling mendasar dan salah satu dari karunia Allah yang terbaik." 38 Kebangkitan

sins; Geoffrey B. Wilson, I Corinthian (Pennsylvania: The banner of Truth Trust, 1978), 214

${ }^{38}$ The resurrection of Jesus assures us God's forgiveness we have already noted that forgiveness is one of our most basic need and one of God's best gifts;" Stott, The Contemporary Christian..., 81 
Kristus adalah buah sulung dari orang-orang yang telah mati, sedangkan ayat 58 menyatakan: "karena itu ... berdirilah teguh jangan goyah..." Paulus memberikan dorongan kepada jemaat Korintus untuk senantiasa berdiri teguh tidak goyah, tentunya hal ini juga memaparkan tentang berdiri teguh dalam hidup yang saleh, hidup tidak bercacat dihadapan Tuhan. Fakta kebangkitan Kristus membuat orang percaya hidup dalam kekudusan, karena adanya pengampunan dosa dan mereka tidak akan mengalami kebinasaan pada kedatangan Tuhan Yesus kedua kali. Fakta Kebangkitan Kristus membuat orang percaya memiliki pengharapan hidup kekal.

\section{Kesaksian dan Dorongan (1Kor 15:10-11, 58)}

Dalam ayat-ayat sebelumnya, Paulus telah menjelaskan mengenai Kristus yang telah mati, dikuburkan dan yang telah bangkit dari kematian. Kebangkitan Kristus adalah merupakan dasar daripada kebangkitan Kristen atau orang percaya. Tuhan Yesus menampakkan diri-Nya kepada para murid dan kepada 500 orang, selain para murid. Sedangkan penampakkan diri kepada Paulus adalah merupakan penampakan Kristus yang paling akhir dari semua urutan penampakan Kristus setelah kebangkitan-Nya. Kristus menampakkan diri-Nya kepada Paulus yaitu pada waktu perjalanan Paulus ke Damsyik. Paulus ke Damsyik dengan tujuan akan menganiaya jemaat Tuhan disana, namun di dalam perjalanan, Paulus ditangkap (bertobat) oleh Tuhan. Paulus yang sebelumnya menentang Tuhan, menjadi murid Tuhan. Karena itulah Paulus menyebut dirinya yang paling hina dari semua rasul. Maksud Paulus disini ialah ia yang telah menganiaya jemaat Tuhan (Kis 8:3; 9:1; 22:4; 26:9-11), namun Tuhan menangkapnya dan mengubahnya menjadi seorang misionaris yang besar (Gal 1:13-16).

Dalam ayat 10a adalah sebagai bukti bahwa Paulus yang adalah paling hina di antara orang kudus, namun dia mendapatkan kasih karunia Allah untuk menjadi alat-Nya, memberitakan kepada orang-orang bukan Yahudi akan kekayaan Kristus yang tidak terduga (Ef 3:8). Dahulu ia adalah orang berdosa yang paling celaka, tetapi Allah menjadikannya contoh hidup yang sempurna tentang bagaimana kasih karunia itu bekerja (1Tim 1:15-16). Hal yang sama juga diungkapkan oleh Pfitzner, bahwa: "Kasih karunia tidak pernah cuma sekedar gagasan atau konsep teologis yang bagus dari Paulus; ia telah mengalami kuasa-Nya di dalam perubahan hidupnya sendiri. Jadi, ia bahkan dapat menyebut jabatannya sebagai rasul sebagai sebuah anugerah kasih karunia (Rm 1:5)." 39 Jadi, disini Paulus

${ }^{39}$ Pfitzner, Kesatuan dalam Kepelbagaian..., 296 
menjelaskan bahwa oleh karena kasih karunia Allah saja, ia dapat melayani Tuhan dengan sungguh-sungguh. Paulus bersaksi: "tetapi aku telah bekerja lebih keras daripada mereka semua." Paulus disini menjelaskan bahwa ia sama sekali tidak lebih rendah dari pada para rasul yang lain, yang suka menonjolkan diri atau menyombongkan kekuatan-kekuatan rohani mereka (2Kor 11:5, 23; 12:11). Karena kasih karunia Allah, Paulus berhasil dalam pelayanan. Bukti keberhasilan Paulus dalam pelayanan yaitu ia telah membuka daerah-daerah baru kemanapun ia pergi atau melayani. Dalam hal ini, Paulus tidak membanggakan usaha-usahanya tetapi "bukannya aku, melainkan kasih karunia Allah yang menyertai aku" yang menghasilkan setiap keberhasilan. Kalimat berikutnya yaitu ayat 11 adalah sebagai kunci dari kalimat-kalimat sebelumnya "sebab itu, baik aku, maupun mereka, kami sama-sama mengajar dan kamu menjadi percaya." Paulus atau para rasul, para misionaris lainnya, hanyalah seorang hamba, yang dengan penuh kesetiaan menunaikan tugas yang telah dipercayakan kepadanya (1 Kor 3:510). Mereka sama-sama mengajarkan kebenaran yang sama, seperti apa yang orang-orang Korintus juga percaya. Dalam ayat 58 ini, Paulus memberikan suatu kesimpulan praktis dari keseluruhan ayat-ayat sebelumnya (ay.1-57), yang telah dijelaskan bahwa kepastian atau pengharapan kebangkitan orang percaya adalah didasarkan pada kebangkitan Kristus sebagai yang sulung dari kebangkitan orang percaya. Karya Kristus telah memuaskan tuntutan Hukum Taurat (bnd. Gal 3:13), dimana kuasa dosa telah Ia hancurkan, maut telah Ia kalahkan.

Kesimpulan pembahasan Paulus adalah himbauan bagi seluruh jemaat Tuhan di Korintus agar berdiri teguh, jangan sampai iman mereka digoyahkan atau digeser oleh dunia, oleh iman yang merusakkan yaitu iman yang tidak benar dan giat didalam melayani Tuhan. Karena pekerjaan atau pelayanan yang sungguh di dalam Tuhan akan menghasilkan buah yaitu iman yang tidak kosong dan perbuatan-perbuatan yang baik. Pernyataan ini tidak memberikan kepada mereka pintu masuk ke dalam sorga, tetapi hanya oleh kasih karunia Allah di dalam Kristus yang memberikannya.

\section{Implikasi Eskatologis (1Kor 15: 20, 42)}

Kata eskatologi dalam bahasa Yunani eshatoj yang memiliki pengertian last; the term refers to the doctrine of the last things." ${ }^{40}$ Berkhof

\footnotetext{
${ }^{40}$ Sin. Ferguson, David F. Wright, "New Dictionarry of Theology," in Lecturer in New Testament, clair BS.H. Travis (Leicester, England: Universities and Colleges Christian Felloship, 1988), 228
} 
menyatakan bahwa eskatologi didasarkan pada ayat-ayat Alkitab yang membicarakan tentang hari-hari terakhir; waktu terakhir atau jam terakhir. ${ }^{41}$ Jadi, yang dimaksud dengan implikasi eskatologi adalah doktrin kebangkitan orang mati membuat Gereja atau orang percaya memiliki pengharapan kebangkitan pada akhir zaman atau pada saat kedatangan Tuhan Yesus yang kedua kali (parousia). Paulus dalam ayat 20 menyatakan: “... bahwa Kristus telah dibangkitkan dari antara orang mati, sebagai yang sulung dari orang-orang yang telah meninggal." John Stott menyatakan bahwa: "Kebangkitan Yesus memberikan jaminan kepada kita mengenai pengampunan Allah. Kita telah mengetahui bahwa pengampunan adalah salah satu kebutuhan yang paling mendasar dan salah satu dari karunia Allah yang terbaik." 42 Paulus dalam hal ini, menekankan bahwa Kristus benar-benar telah dibangkitkan. Ia mau menjelaskan suatu kejadian yang sudah berlalu, tetapi berakibat terus menerus. Kristus menjadi jaminan dari buah yang akan datang, yaitu jemaat-Nya. Kristus bangkit dari kematian langsung ke sorga, tidak hidup dalam dunia ini lagi. Selain itu, kebangkitan Kristus adalah dasar bagi kebangkitan orang percaya, dengan kata lain, kebangkitan Kristus adalah kebangkitan yang menyelamatkan, yang memungkinkan kebangkitan orang mati. Paulus menyatakan bahwa, orang yang telah mati akan ditaburkan (dikuburkan) dalam kebinasaan, maka tubuh orang mati tersebut akan membusuk dan hancur, karena tubuh tersebut bersifat alamiah (ay. 42 ) ${ }^{43}$ Kemudian tubuh itu akan dibangkitkan oleh Allah dengan tubuh yang baru, yang tidak akan binasa, tubuh yang mulia, karena tubuh tersebut bersifat rohaniah. Penekanan Paulus dalam teks ini ialah karya Allah yang membangkitkan tubuh alamiah menjadi tubuh rohani. Jadi, kebangkitan Kristus adalah menjadi dasar bagi kebangkitan orang percaya. Kristus sebagai jaminan atau buah sulung bagi orang percaya atau Gereja. Orang percaya yang telah mati pada akhir zaman akan dibangkitkan dari kematian dan tubuhnya akan diubahkan menjadi tubuh yang baru atau rohani, sedangkan yang masih hidup akan diubahkan dalam sekejap mata (tubuh kemuliaan).

\footnotetext{
${ }^{41}$ Louis Berkhof, Teologi Sistematika 6: Doktrin Akhir Zaman (Jakarta: Lembaga Reformed Injili Indonesia, 1998), 10-11

${ }^{42}$ The resurrection of Jesus assures us God's forgiveness we have already noted that forgiveness is one of our most basic need and one of God's best gifts; Stott, The Contemporary Christian..., 81

${ }^{43}$ The mortal body, perishable (Gal 6:8), dishonored, humiliated because of sin (Phil. 3:20,21), and weak (Mark 14:38) - a natural body like those of the animal worldand bring that body that "is sown" in death (John 12:24); W. Harold Mare, The Expositor's Bible Commentary, in I Corinthians..., 290
} 